REPORTS OF MORPHOLOGY
Official Journal of the Scientific Society of Anatomists,
Histologists, Embryologists and Topographic Anatomists
of Ukraine

\title{
Morphological state of the mucous membrane of the esophagus of patients with postresection manifestations of reflux esophagitis depending on the method of the formation of mechanical esophagus-gastric anastomosis
}

Usenko O.U., Sidyuk A.V., Klimas A.S., Sidyuk O.E., Savenko G.U.

State Enterprise "Shalimov's National Institute of Surgery and Transplantology NAMS of Ukraine", Kyiv, Ukraine

\section{ARTICLE INFO}

Received: 19 July, 2018

Accepted: 14 August, 2018

UDC: $616.329: 611.018 .73: 616-089.86$

CORRESPONDING AUTHOR

e-mail: klimas.andrew@gmail.com Klimas A.S.
The formation of mechanical gastrointestinal anastomosis after esophagectomy is often accompanied by the development in patients various degrees of reflux esophagitis. The aim of the study - to evaluate the pathogistological changes of the esophagus mucosa associated with gastro-esophageal reflux in patients with esophageal cancer and gastroesophageal, junction cancer after surgical treatment, depending on the technique of forming the esophagus-gastric anastomosis. The study included 30 patients who developed a mechanical invagination of the esophagus-gastric anastomosis developed by the Ukrainian patent (study group) and 30 patients who formed the end-toend mechanical circulatory esophagus-gastric anastomosis (comparison group). At 12 months of observation all patients were given fibroesophagogastroduodenoscopy. Endoscopic diagnosis of esophagitis was performed according to a modified Los Angeles classification. To assess the morphological state of the esophageal mucosa, the esophageal mucosal biopsy was performed on the site of anastomosis and morphologically evaluated the severity of the reflux esophagitis. Reflux-associated changes in squamous epithelium of the esophagus were evaluated according to the consensus recommendations of the Esohisto Project. Statistical data analysis was performed using the EZR v statistical analysis package. 1.35 (Saitama Medical Center, Jichi Medical University, Saitama, Japan), a graphical interface to $R$ (The R Foundation for Statistical Computing, Vienna, Austria). In a comparative analysis of frequency characteristics between different groups of patients, the 2 criterion was used; for tables 22 (in the case of a small number of patients ( $<5$ cases), in the study subgroups) Fisher's exact test was used. The differences in the results obtained were considered statistically significant at $p<0.05$, which ensures a $95 \%$ level of probability. It has been established that the frequency with which the microscopic signs of reflux esophagitis are fixed are almost 2 times lower in the group of patients who were formed mechanical invagination esophagus-gastric anastomosis in comparison with the mechanical circular ( $46.7 \%$ vs. $83.3 \%, p<0.05)$, since invagination simulates the reproduction of antireflux properties of the lost gastrointestinal transition. Endoscopically diagnosed cases of reflux esophagitis are additionally supplemented by microscopically detected from $5.9 \%$ of subjects in the study group to $28.6 \%$ of subjects $(p<0.05)$ in the comparison group, which indicates a higher sensitivity histological diagnosis. The signs that are consistently associated with post-resection reflux esophagitis include hyperplasia of the basal layer at both the frequency (86.7\% vs. $100 \%)$ and the severity of the severity $(6.7 \%$ vs. $23.3 \%, p<0.05)$, as well as moderate prolongation of papillae $(30.0 \%$ vs. $66,6 \%, p<0.01)$, according to which the best results were obtained in the group of patients that formed the invagination mechanical esophagus-gastric anastomosis. According to the Esohisto Project criteria, the frequency of both "mild" and "severe" esophagitis in the group of patients that formed the invagination mechanical esophagusgastric anastomosis was lower compared to the group with mechanical circulatory esophagus-gastric anastomosis $(36.7 \%$ and $10.0 \%$ vs. $63.3 \%$ and $20.0 \%, p<0.01$, 
respectively).

Keywords: proximal gastrectomy with esophageal resection, esophagus-gastric anastomosis, post-resection reflux esophagitis, Esohisto Project criteria, Histology; Histopathology.

\section{Introduction}

Analysis of the literature on these issues suggests that that most surgeons around the world use mechanical techniques to form thoracic anastomosis [3, 4, 21].

However, along with convincing benefits, the use of stapling devices somewhat impairs the functional results of operations due to the high level of development of late complications from anastomoses: inflammatory complications (anastomositis, reflux esophagitis) and benign strictures $[7,10,15,17,22]$. Therefore, the key to success, as S.Y. Law [16] notes, is not only a thorough formation of anastomosis, but also the development of new methods aimed at improving the quality of intrathoracic anastomosis after esophagectomy in terms of reducing the level of development of late complications from the anastomosis [21].

Despite the fact that clinical symptoms, endoscopy and $\mathrm{pH}$ monitoring are the most important diagnostic tools for diagnosing reflux esophagitis, however, these tests may give controversial conclusions [1]. Diagnostic difficulties are greatest when symptoms of reflux occur without apparent damage to the esophageal mucosa during normal endoscopy [8]. Recent studies suggest that esophageal biopsy in such cases may play an additional role [27]. Currently published several reports on histological findings in patients with reflux esophagitis, but similar changes were found in patients without signs of reflux esophagitis [12]. That is, individual histological markers showed low diagnostic value, which led to the application of histological scores in the diagnosis of reflux esophagitis. Estimates that take into account the combination of histological parameters associated with extensive acid reflux revealed new perspectives on the role of the esophagus biopsy [27]. That is why research is promising to establish a correlation between endoscopic findings and histological changes in the esophagus [12].

The aim of the study - to evaluate the pathogistological changes of the esophagus mucosa associated with gastroesophageal reflux in patients with esophageal cancer and gastroesophageal, junction cancer after surgical treatment, depending on the technique of forming the esophagusgastric anastomosis.

\section{Materials and methods}

Under observation were 60 patients with esophageal cancer and gastroesophageal junction cancer who were on examination and in-patient treatment at the department of gastrointestinal surgery of the Shalimov's National Institute of Surgery and Transplantation for the period from 2015 to 2018 with overall survival not less than a year. All patients underwent proximal gastrectomy with subtotal esophagectomy by accesses of Lewis, or Osawa-Garlock. The study included 30 patients who were formed mechanical invagination esophagus-gastric anastomosis that was developed and protected by the Ukrainian patent [28] (study group) and 30 patients who formed the circular mechanical esophagus-gastric anastomosis end-to-side (comparison group).

At 12 months of observation all patients performed esophagogastroscopy. Endoscopic examination was performed by video gastroscope Olympus GIF-H180. In doubtful cases, the virtual chromoscopy of NBI was used. Endoscopic diagnosis of esophagitis was performed according to a modified Los Angeles classification. All patients performed a biopsy of the mucous membrane of the esophagus over the place of anastomosis. For histological analysis of biopsy material after routine placement, the dyes were stained with hematoxylin-eosin. The preparations were studied on a light microscope of Olympus BH-2 (lens x10, eyepiece x10; lens x40, eyepiece $\mathrm{x} 10)$. The photos were taken using the DIGITAL Camera for Microscope ScienseLab DCM520 (USB 2.0) digital camera.

Esophageal mucus preparations of the study group and the comparison group were analyzed for the presence of histological signs of reflux esophagitis: hyperplasia of the basal cell layer, papillary prolongation, expansion of intercellular spaces and the presence of intraepithelial eosinophils, neutrophils and mononuclear cells, since these four features are considered the most informative elemental lesions [23]. The combined assessment of microscopic lesions in patients conducted under standardized criteria established Esohisto project, introducing assessment of severity for each parameter in the range of 0 to 2 [8, 26, 31]. In this case:

- basal layer thickness (basal cell layer in $\mu \mathrm{m}$, expressed as a fraction of the total thickness of the epithelium (x10) - 0 (absent)<15\%, 1 - 15-30\%, 2 - >30\%;

- the length of the papillae (the length of the papillae in $\mu \mathrm{m}$, expressed as the percentage (\%) of the thickness of the general epithelium (x10) - 0 (absent)<50\%, 1 - 50-75\%, 2 $>75 \%$;

- expansion of intercellular spaces (Identify as irregular round dilations or diffuse widening of intercellular space (x40), small intercellular space $=$ diameter $<1$ lymphocyte, large intercellular space $=$ diameter $\geq 1$ lymphocyte): 0 (absent or $\leq 5$ small intercellular spaces), 1 (1 lymphocyte or $\geq 6$ small and $\leq 5$ large intercellular spaces), 2 ( $\geq 1$ lymphocyte or $\geq 6$ large intercellular spaces);

- intraepithelial eosinophils (count the cells in the most damaged field (x40)): 0 (absent) 1 - (1-2 cells), 2 (>2 cells);

- intraepithelial neutrophils (count the cells in the most 
damaged field (x40)): 0 (absent) 1 - (1-2 cells), 2 (>2 cells); - intraepithelial mononuclear cells (count the cells in the most damaged field $(x 40))$ : 0 (0-9 cells), 1 (10-30 cells), 2 (>30 cells).

The total figure severity estimates calculated by summing the severity of lesions divided by the estimated lesion types (exclude intraepithelial mononuclear cells and neutrophils, erosion/erosion healed). Scores $0-0.25$ were considered normal, values $\geq 0.35$ were positive for microscopic esophagitis, scores $0.5-0.75$ were qualified for the diagnosis of "mild" esophagitis, and scores $\geq 1$ for the diagnosis of "severe" esophagitis respectively [23, 31].

Statistical analysis of the data was performed using the statistical analysis package EZR v.1.35 (Saitama Medical Center, Jichi Medical University, Saitama, Japan), Graphic interface to R (The R Fund for Statistical Computing, Vienna, Austria). A comparative analysis of the frequency characteristics between different groups of patients using the criterion $x^{2}$, for tables $2 \times 2$ (in the case of a small number of patients ( $<5$ cases) in the study subgroups) used the Fisher exact test $[9,13]$. Differences in the results obtained were statistically significant at $p<0.05$, which provides $95 \%$ probability level.

\section{Results}

At 12 months of follow up of operated patients, endoscopic changes in the esophagus mucosa were not detected in 24 $(40 \%)$ patients: in $17(56.7 \%)$ - in the study group and in 7 (23.3\%) - in comparison groups; morphological confirmation of absence of signs of reflux esophagitis was obtained in 21 (35\%) patients: in $16(53.3 \%)$ and $5(16.7 \%)$ patients respectively (Table 1$)$.

Figure 1 illustrates the absence of signs of postreaction reflux esophagitis: the papillary length is less than half $(<50 \%)$ of the total thickness of the epithelium, the basal layer is only a small percentage $(<15 \%)$ of the total thickness of the epithelium, intercellular spaces are not significantly dilated ( $\leq 5$ small). Intraepithelial eosinophils are absent.

Endoscopic signs of reflux esophagitis detected in 36 $(60.0 \%)$ patients, $13(43.3 \%)$ patients in the study group and $23(76.7 \%)$ patients comparison groups. In addition to endoscopically identified patients with symptoms of reflux esophagitis identified individuals with histological changes and the lack of visible lesions endoscopically: the study group - 1 in the comparison group - 2 patients. Thus, morphologically confirmed reflux esophagitis was detected in $39(65.0 \%)$ patients: in $14(46.67 \%)$ patients in the study group and $25(83.33 \%)$ patients in the comparison group (Table 1).

For histological characteristics of patients found violations of the esophageal mucosa varying degrees regardless of the method of forming esophagus-gastric anastomosis.

Postresection reflux-associated microscopic changes in the esophageal epithelium are given in Table 2.

Multilayer epithelium was detected in $26(86.7 \%)$ persons

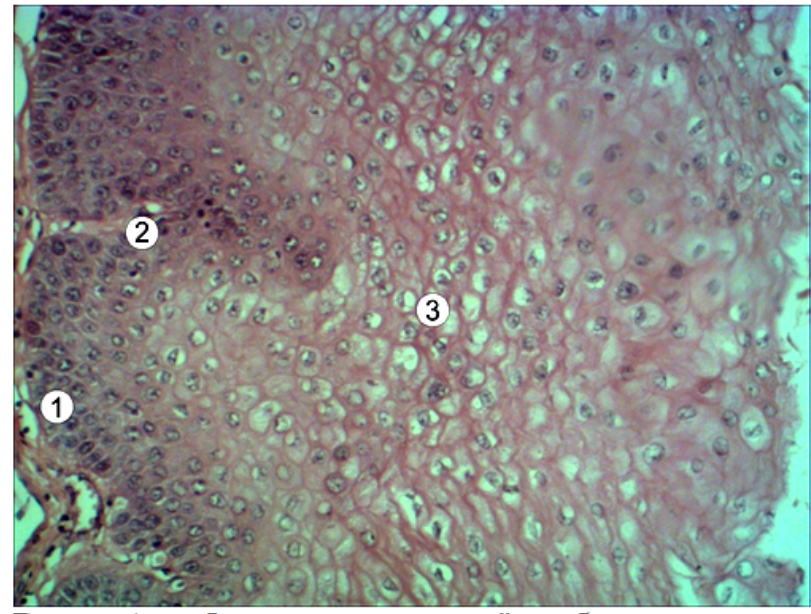

Fig. 1. A fragment of the esophageal mucosa over the place of esophago-gastric anastomosis with no pathological changes. 1 basal layer; 2 - papillae; 3 - intercellular spaces. Hematoxylineosin. Lens $\times 10$. Ocular $\times 10$.

Table 1. Frequency of endoscopic and morphologically confirmed manifestation of reflux esophagitis after 12 months of follow up.

\begin{tabular}{|c|c|c|c|c|c|}
\hline \multirow{2}{*}{$\begin{array}{c}\text { Reflux } \\
\text { esophagitis }\end{array}$} & \multicolumn{2}{|c|}{$\begin{array}{c}\text { Research group, } \\
(n=30)(\%)\end{array}$} & \multicolumn{2}{|c|}{$\begin{array}{c}\text { Comparison } \\
\text { Group, }(n=30)(\%)\end{array}$} & \multirow{2}{*}{$\begin{array}{l}\text { Level of } \\
\text { significance } \\
\text { of difference } \\
\text { between } \\
\text { groups, } p\end{array}$} \\
\hline & $\begin{array}{l}\text { Not } \\
\text { found }\end{array}$ & Detected & $\begin{array}{l}\text { Not } \\
\text { found }\end{array}$ & Detected & \\
\hline $\begin{array}{c}\text { Endoscopically } \\
\text { detected }\end{array}$ & $\begin{array}{c}17 \\
(56.7)\end{array}$ & $\begin{array}{c}13 \\
(43.3)\end{array}$ & $\begin{array}{c}7 \\
(23.3)\end{array}$ & $\begin{array}{c}23 \\
(76.7)\end{array}$ & $<0.05$ \\
\hline $\begin{array}{l}\text { Morphologically } \\
\text { verified }\end{array}$ & $\begin{array}{c}16 \\
(53.3)\end{array}$ & $\begin{array}{c}14 \\
(46.7)\end{array}$ & $\begin{array}{c}5 \\
(16.7)\end{array}$ & $\begin{array}{c}25 \\
(83.3)\end{array}$ & $<0.01$ \\
\hline
\end{tabular}

in the study group and in $30(100 \%)$ persons - groups of comparison, extension of the papillae - respectively in 14 $(46.7 \%)$ and 25 (83.3\%) persons, enlargement intercellular spaces and intraepithelial eosinophils were detected in 3 $(10.0 \%)$ persons in the study group and in $6(20.0 \%)$ persons in the comparison group (Table 2). That is, the most common reflux-associated histological signs, according to Table 2, include an increase in the thickness of the basal layer, which is $15-30 \%$ relative to the total thickness of the epithelium (1) and papilla extension, which is $50-75 \%$ relative to the total thickness of the epithelium (1). Less dilatation of small intercellular spaces (1) and the presence of intraepithelial eosinophil in one field (1) are observed. However, the degree of histological changes in the mucous membrane of the esophagus, according to which the study groups differed 3 times, ranged as 2 - were inherent in only hyperplasia of the basal layer. In assessing the degree of change as 1 elongation of the papillae, according to which the study groups differed 2 times, as well as - dilatation of intercellular spaces and the presence of intraepithelial eosinophils, however, in the last two cases, the number of persons having such changes was insignificant (Table 2). Figure 2 illustrates the signs of postreaction reflux esophagitis, which is accompanied by an increase in the thickness of the basal layer, prolongation of the papillae $(<75 \%)$, and the dilatation of the intercellular spaces. 
Table 2. Degree of severity of reflux esophagitis by microscopic diagnosis of Esohisto Project.

\begin{tabular}{|c|c|c|c|c|}
\hline Criterion & Severity & $\begin{array}{l}\text { Research } \\
\text { group, } \mathrm{n} \\
(\%)\end{array}$ & $\begin{array}{l}\text { Comparison } \\
\text { Group, n (\%) }\end{array}$ & $\begin{array}{c}\text { Level of } \\
\text { significance } \\
\text { of difference } \\
\text { between } \\
\text { groups, p }\end{array}$ \\
\hline $\begin{array}{l}\text { Hyperplasia of } \\
\text { the basal layer }\end{array}$ & $\begin{array}{l}0 \\
1 \\
2\end{array}$ & $\begin{array}{c}4(13.3) \\
24(80.0) \\
2(6.7)\end{array}$ & $\begin{array}{c}0(0.0) \\
23(76.7) \\
7(23.3)\end{array}$ & $<0.05$ \\
\hline $\begin{array}{l}\text { Papillary } \\
\text { elongation }\end{array}$ & $\begin{array}{l}0 \\
1 \\
2\end{array}$ & $\begin{array}{c}16 \\
(53.3) 9 \\
(30.0) 5 \\
(16.7)\end{array}$ & $\begin{array}{c}5(16.7) \\
20(66.6) \\
5(16.7)\end{array}$ & $<0.01$ \\
\hline $\begin{array}{l}\text { Expansion of } \\
\text { intercellular } \\
\text { spaces }\end{array}$ & $\begin{array}{l}0 \\
1 \\
2\end{array}$ & $\begin{array}{c}27(90.0) \\
2(6.7) \\
1(3.3)\end{array}$ & $\begin{array}{c}24(80.0) \\
5(16.7) \\
1(3.3)\end{array}$ & $>0.05$ \\
\hline $\begin{array}{l}\text { Intraepithelial } \\
\text { eosinophils }\end{array}$ & $\begin{array}{l}0 \\
1 \\
2\end{array}$ & $\begin{array}{c}27(90.0) \\
2(6.7) \\
1(3.3)\end{array}$ & $\begin{array}{c}24(80.0) \\
5(16.7) \\
1(3.3)\end{array}$ & $>0.05$ \\
\hline
\end{tabular}

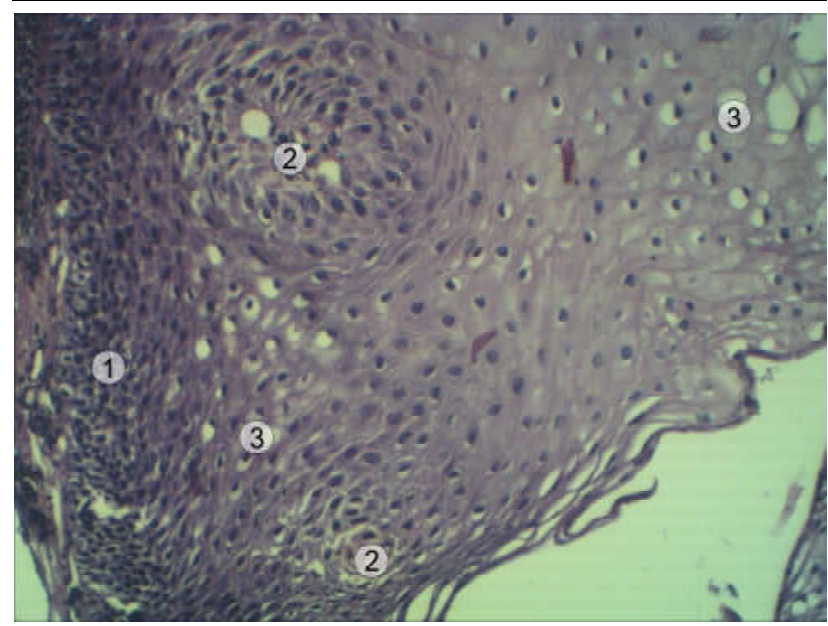

Fig. 2. A fragment of the esophageal mucosa over the place of esophago-gastric anastomosis with pathological changes. 1 - basal layer; 2 - elongated papillae; 3 - dilated intercellular spaces. Hematoxylin-eosin. Lens x10. Ocular x10.

Table 3. Distribution of ballroom characteristics of patients and aggregate indicator of severity of histological changes of the mucous membrane.

\begin{tabular}{|c|c|c|c|}
\hline Severity & Score & $\begin{array}{c}\text { Research group. } \mathrm{n} \\
(\%)\end{array}$ & $\begin{array}{c}\text { Comparison Group. } \mathrm{n} \\
(\%)\end{array}$ \\
\hline Norm & $<0.5$ & $16(53.4)$ & $5(16.7)$ \\
\hline \multirow{2}{*}{$\begin{array}{c}\text { "Mild" } \\
\text { esophagitis }\end{array}$} & 0.5 & $7(23.3)$ & $12(40.0)$ \\
\cline { 2 - 4 } & 0.75 & $4(13.4)$ & $7(23.3)$ \\
\hline \multirow{2}{*}{$\begin{array}{c}\text { "Severe" } \\
\text { esophagitis }\end{array}$} & 1 & $1(3.3)$ & $1(3.3)$ \\
\cline { 2 - 4 } & 1.25 & $1(3.3)$ & $4(13.4)$ \\
\cline { 2 - 4 } & 2 & $1(3.3)$ & $1(3.3)$ \\
\hline
\end{tabular}

Based on detected reflux-associated microscopic changes in the epithelium of the esophagus, the distribution of patients according to the degree of severity of histological changes in the mucous membrane was further analyzed (Table 3).
In the group in which patients were formed invagination mechanical esophagus-gastric anastomosis, reflux esophagitis was detected in 14 (46.7\%) patients versus 25 $(83.3 \%)$ in patients who had circular mechanical esophagusgastric anastomosis (Table 1, 3). Histological "mild" esophagitis was found in 11 patients $(36.7 \%)$ in the study group and in 19 patients $(63.3 \%)$ of the comparison group, "severe" esophagitis - in $3(10 \%)$ and $6(20 \%)$ of patients respectively, the difference between the groups is statistically significant ( $p=0.03$ according to the 2 criterion) (Table 3 ). At the same time, the vast majority of patients whose esophagitis were classified as "mild", were scored by 0.5 points in both groups. Among patients with esophagitis are classified as "severe", attracts comparison group in which the majority of patients met the 1.25 point scale characterization, while in the comparison group points evenly distributed (Table. 3).

The results of the comparison of the severity of the reflux esophagitis associated with the endoscopic diagnosis of esophagitis, evaluated according to the Los Angeles classification and evaluated according to the histological criteria of Esohisto Project, are presented in Table 4.

The reflux esophagitis according to the Los Angeles Classification of Grade A was found in 10 (33.3\%) patients, grade B - in $3(10.0 \%)$ patients in the study group and accordingly in $18(60.0 \%)$ and $5(16.7 \%)$ of the patients in the comparison group. At the same time, according to the histological criteria, Esohisto's "mild" esophagitis was detected in $11(36.7 \%)$ patients, and severe in $3(10.0 \%)$ patients in the study group and $19(63.3 \%)$, respectively, and $6(20.0 \%)$ patients in the comparison group (Table 4$)$. That is, endoscopically diagnosed cases of reflux esophagitis were

Table 4. Compliance with the severity of the reflux esophagitis associated with the endoscopic diagnosis of esophagitis. evaluated according to the Los Angeles classification and evaluated according to the histological criteria of the Esohisto Project.

\begin{tabular}{|c|c|c|c|}
\hline Category & $\begin{array}{c}\text { Research } \\
\text { group, } \mathrm{n}(\%)\end{array}$ & $\begin{array}{c}\text { Comparison } \\
\text { Group, } \mathrm{n}(\%)\end{array}$ & $\begin{array}{c}\text { Level of } \\
\text { significance of } \\
\text { difference } \\
\text { between groups }\end{array}$ \\
\hline
\end{tabular}

\begin{tabular}{|c|c|c|c|}
\hline \multicolumn{4}{|c|}{ Los Angeles Classification } \\
\hline $\mathrm{N}$ & $17(56.7)$ & 7 (23.3) & \multirow{4}{*}{$<0.05$} \\
\hline LA-A & $10(33.3)$ & $18(60.0)$ & \\
\hline LA-B & $3(10.0)$ & $5(16.7)$ & \\
\hline LA-C & $0(0.0)$ & $0(0.0)$ & \\
\hline $\begin{array}{c}\text { Detected changes in } \\
\text { general }\end{array}$ & $13(43.3)$ & $23(76.7)$ & $<0.05$ \\
\hline \multicolumn{4}{|l|}{ Esohisto Project } \\
\hline $\begin{array}{l}\text { Mucus without } \\
\text { changes }\end{array}$ & $16(53.3)$ & $5(16.7)$ & \multirow{3}{*}{$<0.01$} \\
\hline "Mild" esophagitis & $11(36.7)$ & $19(63.3)$ & \\
\hline $\begin{array}{l}\text { "Severe" } \\
\text { esophagitis }\end{array}$ & $3(10.0)$ & $6(20.0)$ & \\
\hline $\begin{array}{c}\text { Detected changes in } \\
\text { general }\end{array}$ & $14(46.7)$ & $25(83.3)$ & $<0.01$ \\
\hline
\end{tabular}




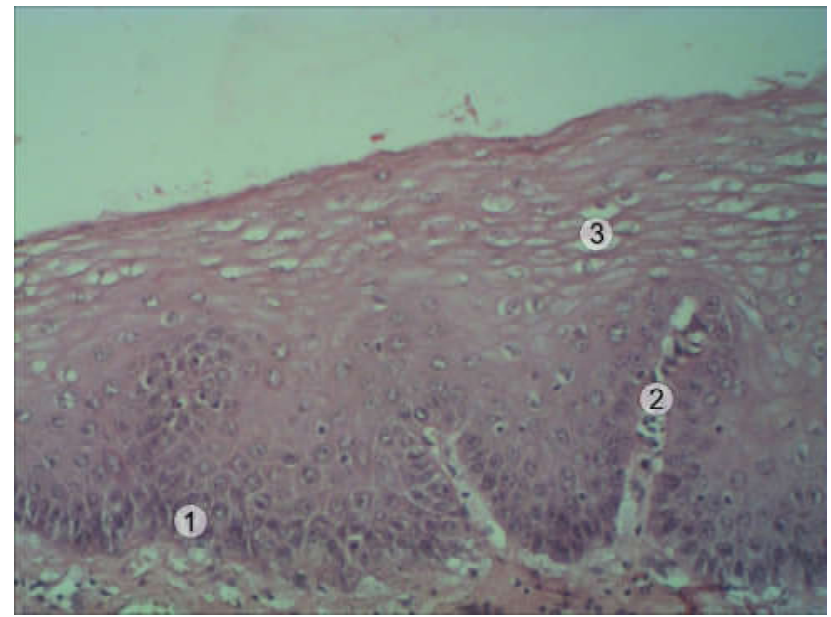

Fig. 3. A fragment of the esophageal mucosa over the place of esophago-gastric anastomosis with pathological changes that correspond to the "mild" reflux esophagitis. 1 - basal layer; 2 elongated papillae; 3 - slightly enlarged intercellular spaces. Hematoxylin-eosin. Lens x10. Ocular x10.

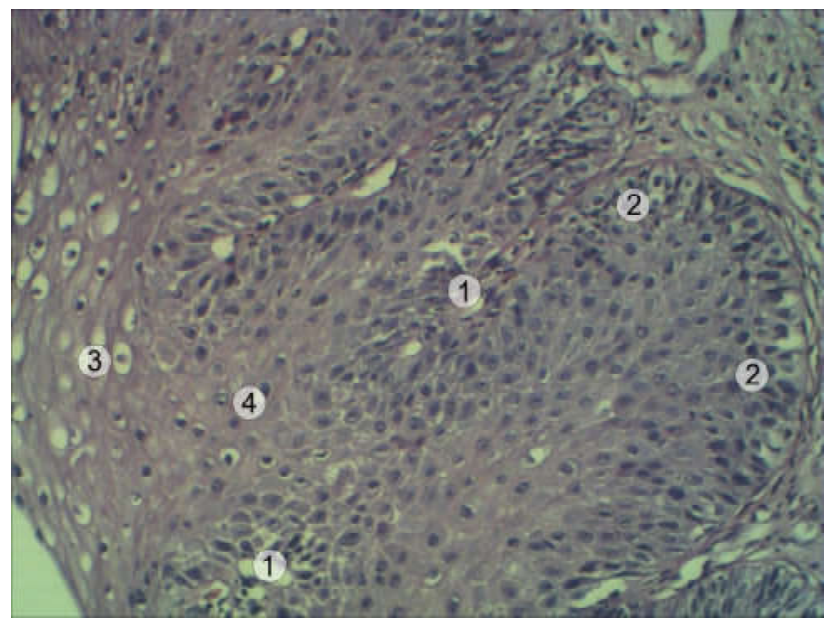

Fig. 4. A fragment of the esophageal mucosa over the place of esophago-gastric anastomosis with pathological changes that correspond to "severe" reflux esophagitis. 1 - elongated papillae; 2 - thickened basal layer; 3 - extended intercellular spaces; 4 intraepithelial eosinophils. Hematoxylin-eosin. Lens x10. Ocular $\mathrm{x} 10$.

additionally supplemented by microscopically detected from $5.9 \%$ of the subjects in the study group to $28.6 \%$ of the subjects in the comparison group with the normal mucous membrane of the esophagus in the category $\mathrm{N}$ classification of Los Angeles (Table 4). It should be noted that in the invagination mechanical method of forming the esophagus-gastric anastomosis, the ratio of "mild"/"severe" esophagitis in the group was almost $4 / 1$, and at the circular - 3/1. That is, regardless of the method of forming the esophagus-gastric anastomosis, the "mild" esophagitis was more often compared to "severe" (Table 4). At the same time, the combined evaluation of microscopic lesions Esohisto Project, the frequency of reflux esophagitis generally in the study group was significantly lower compared to the comparison group (14 $(46.7 \%)$ compared to $25(83.3 \%), p<0.01)$. In this case, the frequency of both "mild" and "severe" esophagitis in the group of patients who formed the invagination mechanical esophagus-gastric anastomosis, was lower compared to the group with circular mechanical esophagus-gastric anastomosis $(36.7 \%$ and $10.0 \%$ vs. $63.3 \%$ and $20.0 \%, p<0.01$ respectively). Histology esophageal mucosa, corresponding to the degree of reflux esophagitis $A$ is characterized by increased length of papillae, representing $50-75 \%$ of the total thickness of the epithelium. Basal layer is increased in thickness and is $15-30 \%$ of the total thickness of the epithelium. Intercellular spaces are slightly extended. There are no intra-epithelial eosinophils (Fig. 3).

Histology esophageal mucosa of patients that meets reflux esophagitis stage $B$, characterized by elongation of papillae, representing $>75 \%$ of the total thickness of the epithelium, increased basal layer in thickness, representing $>30 \%$ of the total thickness of the epithelium, intercellular spaces greatly expanded. Presence of intraepithelial eosinophils (Fig. 4).

\section{Discussion}

In normal esophageal lumen lays out a squamous epithelium, consisting of four layers: basal, parabasal, intermediate and superficial. Epitheliocytes are connected by adhesive, slit, dense and desmosomic contacts, that are located in the intermediate layer [24]. Reactive squamous epithelium changes in response to the action of acid, form the basis of histological diagnostics of reflux esophagitis.

Analyzing the obtained data, it should be noted that the endoscopically normal mucosa of the esophagus of patients after esophagectomy for 12 months of observation was almost 2.5 times more frequent $(56.7 \%$ vs. $23.3 \%$, p $<0.05)$, and the frequency with which fixed the microscopic signs of reflux esophagitis, was almost 2 times lower $(46,67 \%$ vs. $83,33 \%, p<0,05)$ in patients who were formed by invagination mechanical esophagus-gastric anastomosis in comparison with the circular mechanical esophagus-gastric anastomosis, since the invagination modeled the reproduction of antireflux properties of the lost of gastroesophageal junction (see Table. 1, 4).

It should be noted that in addition to endoscopically diagnosed, microscopic changes with signs of reflux esophagitis were found in 1 out of $17(5.9 \%)$ subjects in the study group and in 2 out of $7(28.6 \%)$ persons in the comparison group with normal mucous membrane esophagus according to the Los Angeles Class $\mathrm{N}$ classification, which indicates a higher $(p<0.05)$ sensitivity to the histological diagnosis (see Table 4). About the absence of endoscopic visible lesions, but the presence of histological changes of squamous epithelium in non-aerosive reflux disease is reported by a number of researchers [8, 19, 29].

According to the histological study conducted by us, hyperplasia of the basal layer can be considered a feature that is consistently associated with post-resection reflux esophagitis both in frequency and severity. Normally, the basal layer of the esophagus consists of 2-6 layers of basal 
cells, which is $<15 \%$ of the total thickness of the epithelium $[2,8,26,31]$. The multilayer squamous epithelium was detected in the vast majority of patients in the study group $(86.67 \%)$ and in all patients in the comparison group (100\%). However, the number of patients with more severe severity (2) was 3 times less $(p<0.05)$ among patients who were formed by invagination mechanical esophagus-gastric anastomosis in comparison with the circular mechanical esophagus-gastric anastomosis (Table 2). In healthy individuals, the papilla's length is less than $50 \%$ of the total thickness of the epithelium [23, 26, 31]. Papillary elongation, accounting for $50-75 \%$ and $75 \%$ relative to the total thickness of the epithelium was found in $14(46.7 \%)$ patients in group study and 25 (83.3\%) patients comparison group (difference between groups is statistically significant, $p<0.01)$. In addition, the number of patients with a more moderate degree of severity (1) was 2 times lower $(p<0.05)$ among patients who were formed by invagination mechanical esophagus-gastric anastomosis in comparison with the circular mechanical esophagus-gastric anastomosis, indicating its benefits (Table 2). The good diagnostic value of these two parameters in the GERD is indicated by $M$. Vieth [30]. According to some researchers, hyperplasia of the basal layer and extension of the stromal papillae represent a regenerative reaction to damage to the mucous membrane caused by reflux ("hyperregeneration") [6, 11, 18, 26]. However, for normal esophageal epithelium characterized by low regenerative property: moving cells from the basal layer to the surface proceeds 30 days [20]. Expansion of intercellular spaces and the presence of intraepithelial eosinophils occurred occasionally: $10.0 \%$ in the study group and $20.0 \%$ in the comparison group $(p>0.05)$, with the number of patients with a more moderate degree of severity (1) was almost 2 times less (but did not achieve a significant difference) among patients who were formed by invagination mechanical esophagus-gastric anastomosis (Table 2). According to literature in the epithelium of the esophagus in patients with non-erosive reflux disease, expanded intercellular spaces are detected, the mean diameter of which in the distal esophagus is three times higher compared to control [5].

We found that the ratio of the frequency of "mild" and "severe" esophagitis does not depend on the method of forming esophagus-gastric anastomosis: the histologically "mild" esophagitis is found in 3 times more often than in the "severe". However, the frequency of both "mild" and "severe" esophagitis according to the criteria of Esohisto Project in the study group was 2 times lower compared with the comparison group $(36.7 \%$ and $10.0 \%$ vs. $63.3 \%$ and $20.0 \%$, respectively. $p<0.01$ ) (Table 4 ). In conclusion, it should be noted that recent studies have shown that histological evaluation based on a combination of histological parameters may be largely due to patient symptoms and esophageal acid exposure and thus can contribute not only to the diagnosis of non-erosive reflux disease, but and differential diagnosis between patients with non-erosive reflux disease and patients with functional heartburn [14, 25 ] and play a role in the comparative evaluation of various therapies [23]. Thus, the results of the study indicate that the formation invagination mechanical esophagus-gastric anastomosis significantly reduces histological signs of reflux esophagitis compared to the mechanical method of forming a circular mechanical esophagus-gastric anastomosis, and the use of histological severity ratings showed promising results when assessing the quality of new ways of forming esophagus-gastric anastomosis.

\section{Conclusions}

1. Histologically normal mucosa of the esophagus of patients after esophagectomy for 12 months of follow up was found more than 2 times more often in the group of patients who were formed mechanical invagination esophagus-gastric anastomosis compared with circular mechanical esophagus-gastric anastomosis (53.3\% vs. $16.7 \%, p<0.05$ in accordance).

2. According to the histological study, the frequency of reflux esophagitis is almost 2 times lower in the group of patients who were formed mechanical invagination esophagus-gastric anastomosis compared with circular mechanical esophagus-gastric anastomosis $(46.7 \%$ vs. $83.3 \%, p<0.05)$, since invasion models the reproduction of antireflux properties of lost gastroesophageal junction.

3. The combination of histological parameters in patients with morphologically confirmed post-resection reflux esophagitis appears to be in the vast majority of cases, such as hyperplasia of the basal layer and elongation of the papillae of predominantly moderate severity, occasionally supplemented by the dilation of small intercellular spaces and single intraepithelial eosinophils.

4. Among patients with mechanical invagination esophagus-gastric anastomosis, the number of patients with hyperplasia of the basal layer of severe severity (2) was 3 times smaller $(6.7 \%$ vs. $23.3 \%, p<0.05)$, and the number of patients with papillary elongation ( $30.0 \%$ vs. $66.6 \%, p<0.01$ ), the expansion of intercellular spaces and the presence of intraepithelial eosinophils of moderate severity (1) $(6.7 \%$ versus $16.7 \%, p>0.05$ ) was in 2 times less, compared with patients who formed a circular mechanical esophagogastroanastomosis, which confirms the advantages of mechanical invagination esophagus-gastric anastomosis.

5. The degree of severity of esophagitis evaluated according to the Esohisto Project criteria, the frequency of both "mild" and "severe" esophagitis in the group of patients who was formed mechanical invagination esophagus-gastric anastomosis was 2 times lower compared with the group with circular mechanical esophagus-gastric anastomosis ( $36,7 \%$ and $10.0 \%$ vs. $63.3 \%$ and $20.0 \%$, p $<0.01$ respectively).

6 . The histological diagnosis of reflux esophagitis in postresection patients is more sensitive than endoscopic, since it allows individuals with a lack of endoscopic visible lesions of the esophagus mucosa to detect individuals with microscopic signs of reflux esophagitis. 


\section{References}

[1] Allende, D. S., \& Yerian, L. M. (2009). Diagnosing gastroesophageal reflux disease: the pathologist's perspective. Adv. Anat. Pathol., 16(3), 161-165. doi: 10.1097/ PAP.0b013e3181a186a3.

[2] Behar, J., \& Sheahan, D. (1975). Histologic abnormalities in reflux esophagitis. Arch. Pathol., 99(7), 387-391. Retrieved from: https://www.ncbi.nlm.nih.gov/pubmed/238497.

[3] Biere, S. S., Maas, K. W., Cuesta, M. A., \& van der Peet, D. L. (2011). Cervical or Thoracic Anastomosis after Esophagectomy for Cancer: a systematic review and metaanalysis. Dig. Surg., 28 (1), 29-35. doi: 10.1159/000322014.

[4] Bogopolsky, P. M., Balalykin, D. A., \& Chernousov, F. A. (2012). To the history of the development and use of sewing apparatuses in the surgery of the esophagus in Russia. Bulletin of Surgical Gastroenterology, 1, 66-71. ISSN: 20727984.

[5] Caviglia, R., Ribolsi, M., Gentile, M., Rabitti, C., Emerenziani, S., Guarino, M. P. ... Cicala, M. (2007). Dilated intercellular spaces and acid reflux at the distal and proximal oesophagus in patients with non-erosive gastro-oesophageal reflux disease. Aliment. Pharmacol. Ther., 25(5), 629-636. DOI: 10.1111/ j.1365-2036.2006.03237.x.

[6] Dent, J. (2007). Microscopic esophageal mucosal injury in nonerosive reflux disease. Clin. Gastroenterol. Hepatol., 5(1), 4-16. DOI: 10.1016/j.cgh.2006.08.006.

[7] Dong Zhou, Quan-Xing Liu, Xu-Feng Deng, Jia-Xin Min, \& JiGang Dai (2015). Comparison of two different mechanical esophagogastric anastomosis in esophageal cancer patients: a meta-analysis. J. Cardiothorac. Surg., 10, 67. https://doi.org/ 10.1186/s13019-015-0271-4.

[8] Fiocca, R., Mastracci, L., Riddell, R., Takubo, K., Vieth, M., Yerian, L. ... Ruth, M. (2010). Development of consensus guidelines for the histologic recognition of microscopic esophagitis in patients with gastroesophageal reflux disease: the Esohisto project. Hum. Pathol., 41(2), 223-231. doi: 10.1016/ j.humpath.2009.07.016.

[9] Guryanov, V. G., Lyakh, Yu. E., Pari, V. D., Korotkyy, O. V., Chaly, O. V., Chaly, K. O., \& Tsekhmyster, Ya. V. (2018). Biostatistics guide. Analysis of the results of medical research in the EZR package (R-statistics): tutorial. K.: Vistka.

[10] Honda, M., Kuriyama, A., Noma, H., Nunobe, S., \& Furukawa, T. A. (2013). Hand-sewn versus mechanical esophagogastric anastomosis after esophagectomy: a systematic review and meta-analysis. Ann. Surg., 257(2), 238-248. DOI:10.1097/ SLA.0b013e31826d4723.

[11] Ismail-Beigi, F., Horton, P. F., \& Pope, C. E. 2nd (1970). Histological consequences of gastroesophageal reflux in man. Gastroenterology, 58(2), 163-174. Retrieved from: https:// www.ncbi.nlm.nih.gov/pubmed/5413015.

[12] Kaiyo Takubo, Naoko Honma, Gopi Aryal, Motoji Sawabe, Tomio Arai, Yasuo Tanaka ... Katsuhiko Iwakiri (2005). Is There a Set of Histologic Changes That Are Invariably Reflux Associated? Arch. Pathol. Lab. Med., 129(2), 159-163. DOI: 10.1043/1543-2165(2005)129<159:ITASOH>2.0.CO;2.

[13] Kanda, Y. (2013). Investigation of the freely available easy-touse software 'EZR' for medical statistics. Bone Marrow Transplant., 48, 452-458.

[14] Kandulski, A., Jechorek, D., Caro, C., Weigt, J., Wex, T., M?nkem?ller, K., \& Malfertheiner, P. (2013). Histomorphological differentiation of non-erosive reflux disease and functional heartburn in patients with PPI-refractory heartburn. Aliment. Pharmacol. Ther., 38(6), 643-651. doi: 10.1111/apt.12428.

[15] Kovalchuk, A. V. (2004). The choice of a method for the formation of anastomosis in the surgical treatment of patients with esophageal and stomach cancer with the transition to the esophagus. (Dis. cand. med. sci.). AMS of Ukraine. Institute of Oncology, Kyiv.

[16] Law, S. Y. (2012). The Art and Science of Esophageal Anastomosis. In Innovation in Esophageal Surgery, 95-102. doi: 10.1007/978-88-470-2469-4_12.

[17] Liu, Q. X., Min, J. X., Deng, X. F., \& Dai, J. G. (2014). Is hand sewing comparable with stapling for anastomotic leakage after esophagectomy? A meta-analysis. World J. Gastroenterol., 20(45), 17218-26. doi: 10.3748/wjg.v20.i45.17218.

[18] Livstone, E. M., Sheahan, D. G., \& Behar, J. (1977). Studies of esophageal epithelial cell proliferation in patients with reflux esophagitis. Gastroenterology, 73, 1315-1319. PMID: 913973.

[19] Lundell, L., Dent, J., \& Bennett, J. (1999). Endoscopic assessment of esophagitis: clinical and functional correlates and further validation of Los Angeles classification. Gut, 45, 172-180. PMID:10403727; PMCID:PMC1727604.

[20] Lutsik, O., Ivanova-Sogomonyan, A., Kabak, K., \& Tchaikovsky, Yu. (2018). Human histology. (3rd ed.). Kyiv: The book plus. http://chtyvo.org.ua/authors/Lutsyk_Oleksandr/ Histolohiia_liudyny/

[21] Maas, K. W., Biere, S. S. A. Y., Scheepers, J. J. G., Gisbertz, S. S., Turrado Rodriguez, V., van der Peet, D. L., \& Cuesta, M. A. (2012). Minimally invasive intrathoracic anastomosis after Ivor Lewis esophagectomy for cancer: a review of transoral or transthoracic use of staplers. Surg. Endosc., 26(7), 17951802. doi: 10.1007/s00464-012-2149-z.

[22] Markar, S. R., Karthikesalingam, A., Vyas, S., Hashemi, M., \& Winslet, M. (2011). Hand-Sewn Versus Stapled Oesophagogastric Anastomosis: Systematic Review and Meta-analysis. Journal of Gastrointestinal Surgery, 15(5), 876-884. doi: 10.1007/s11605-011-1426-9.

[23] Mastracci, L., Spaggiari, P., Grillo, F., Zentilin, P., Dulbecco, P., Ceppa, P. ... Fiocca, R. (2009). Microscopic esophagitis in gastro-esophageal reflux disease: individual lesions, biopsy sampling, and clinical correlations. Virchows Arch., 454(1), 31-39. doi: $10.1007 / \mathrm{s} 00428-008-0704-8$.

[24] Orlando, R. C. (2010). The integrity of the esophageal mucosa. Balance between offensive and defensive mechanisms. Best Pract. Res. Clin. Gastroenterol., 24(6), 873-882. doi: 10.1016/ j.bpg.2010.08.008.

[25] Savarino, E., Zentilin, P., Mastracci, L., Dulbecco, P., Marabotto, E., Gemignani, L. ... Savarino, V. (2013). Microscopic esophagitis distinguishes patients with non-erosive reflux disease from those with functional heartburn. $J$. Gastroenterol., 48(4), 473-482. doi: 10.1007/s00535-0120672-2.

[26] Schneider, N. I., \& Langner, C. (2015) The Status of Histopathology in the Diagnosis of Gastroesophageal Reflux Disease - Time for Reappraisal? J. Gastrointest. Dig. Syst., 5, 355. doi:10.4172/2161-069X.1000355.

[27] Triantos Ch., Koukias N., Karamanolis G., \& Thomopoulos K. (2015). Changes in the esophageal mucosa of patients with non erosive reflux disease: How far have we gone? World J. Gastroenterol., 21(19), 5762-5767. doi: 10.3748/ wjg.v21.i19.5762.

[28] Usenko, O. Yu., Sidyuk, A. V., \& Klimas, A. S. (2016). Method 
of performing esophagectomy. Patent of Ukraine №107325, IPC: A61B 17/00 A61B 17/115. Kyiv: State Patent Office.

[29] Vakil, N., van Zanten, S. V., Kahrilas, P., Dent, J., \& Jones, R. (2006). The Montreal definition and classification of gastroesophageal reflux disease: a global evidence-based consensus. Am. J. Gastroenterol., 101(8), 1900-1920. DOI:10.1111/j.1572-0241.2006.00630.x.

[30] Vieth, M., Peitz, U., Labenz, J., Kulig, M., Nauclér, E., Jaspersen, D. ... Stolte, M. (2004). What parameters are relevant for the histological diagnosis of gastroesophageal reflux disease without Barrett's mucosa? Dig. Dis., 22(2), 196-201. DOI:10.1159/000080319.

[31] Yerian, L., Fiocca, R., Mastracci, L., Riddell, R., Vieth, M., Sharma, P. ... Ruth, M. (2011). Refinement and reproducibility of histologic criteria for the assessment of microscopic lesions in patients with gastroesophageal reflux disease: the Esohisto Project. Dig. Dis. Sci., 56(9), 2656-2665. doi: 10.1007/s10620011-1624-z.

\section{МОРФОЛОГІЧНИЙ СТАН СЛИЗОВОЇ ОБОЛОНКИ СТРАВОХОДУ ХВОРИХ З ПОСТРЕЗЕКЦІЙНИМИ ПРОЯВАМИ РЕФЛЮКС- ЕЗОФАГІТУ ЗАЛЕЖНО ВІД СПОСОБУ ФОРМУВАННЯ МЕХАНІЧНОГО СТРАВОХІДНО-ШЛУНКОВОГО АНАСТОМОЗУ \\ Усенко О.Ю., Сидюк А.В., Клімас А.С., Сидюк О.Є., Савенко Г.Ю.}

Формування механічних стравохідно-шлункових анастомозів після езофагектомії нерідко супроводжується розвитком у пацієнтів рефлюкс-езофрагіту різного ступеня. Мета роботи - оцінити патогістологічні зміни слизової оболонки стравоходу, пов'язані з шлунково-стравохідним рефрлюксом, хворих на рак стравоходу та кардіоезофрагіальний рак після радикального оперативного втручання залежно від варіанту сфрормованого езофагогастроанастомозу. До дослідження включені 30 пацієнтів, котрим було сформовано розроблений $і$ захищений патентом України механічний інвагінаційний езофагогастроанастомоз (група дослідження) і 30 хворих, котрим було сфрормовано механічний циркулярний езофагогастроанастомоз кінець в бік (група порівняння). На 12 місяць спостереження усім хворим проведена фіброезофрагогастродуоденоскопія. Ендоскопічну діагностику езофрагіту проводили відповідно до модифікованої Лос-Анджелеської класифрікації. Для оцінки морфрологічного стану слизової оболонки стравоходу виконували біопсію слизової оболонки стравоходу над місцем анастомозу та морфрологічно оцінювали вираженість рефрлюкс-езофагіту. Рефрлюксасоційовані зміни плоского епітелію стравоходу оцінювали згідно із консенсусними рекомендаціями Esohisto Project. Cтатистичний аналіз даних проведений з використанням пакету статистичного аналізу EZR v.1.35 (Saitama Medical Center, Jichi Medical University, Saitama, Japan), графрічний інтерфрейс до R (The R Foundation for Statistical Computing, Vienna, Austria). При порівняльному аналізі частотних характеристик між різними групами пацієнтів використовували критерій 2 , для таблиць 22 (у випадку малої кількості пацієнтів (<5 випадків) у підгрупах дослідження) використано точний критерій Фішера. Розбіжності отриманих результатів вважали статистично значущими при p<0,05, що забезпечує $95 \%$ рівень ймовірності. Встановлено, що, частота, з якою фіксуються мікроскопічні ознаки рефлюкс-езофагіту, майже у 2 рази нижча у групі хворих, яким було сформовано механічний інвагінаційний езофрагогастроанастомоз порівняно з механічним циркулярним $(46,7 \%$ проти 83,3\%, р<0,05), оскільки інвагінація моделює відтворення антирефрлюксних властивостей втраченого стравохідно-шлункового переходу. Ендоскопічно діагностовані випадки рефлюкс-езофагіту додатково доповнюються мікроскопічно виявленими від 5,9\% осіб у групі дослідження до $28,6 \%$ осіб $(p<0,05)$ у групі порівняння, що свідчить про більш високу чутливість гістологічного діагнозу. До ознак, які стійко пов'язані з пострезекційним рефрлюксезофрагітом віднесено гіперплазію базального шару як за частотою (86,7\% проти 100\%), так і за більш тяжким ступенем вираженості (6,7\% проти 23,3\%, p<0,05), а також помірне видовження сосочків (30,0\% проти 66,6\%, p<0,01), за якими кращі результати отримані в групі хворих, котрим сформовали інвагінаційний механічний езофрагогастроанастомоз. За критеріями Esohisto Project частота як "м'якого", так і "важкого" езофрагіту в групі хворих, котрим сформований інвагінаційний механічний езофрагогастроанастомоз, була нижчою порівняно з групою з механічним циркулярним езофрагогастроанастомозом (36,7\% i 10,0\% проти 63,3\% і 20,0\%, p<0,01 відповідно). Таким чином, формування інвагінаційного механічного езофрагогастроанастомозу дозволяє достовірно зменшити частоту гістологічних проявів рефрлюкс-езофагіту порівняно зі способом формування циркулярного механічного анастомозу.

Ключові слова: проксимальна резекція шлунку з резекцією стравоходу, езофагогастроанастомоз, пострезекційний рефрлюксезосрагіm, критерії Esohisto Project, гістологія, гістопатологія.

\section{МОРФОЛОГИЧЕСКОЕ СОСТОЯНИЕ СЛИЗИСТОЙ ОБОЛОЧКИ ПИЩЕВОДАБОЛЬНЫХ С ПОСТРЕЗЕКЦИОННЫМИ ПРОЯВЛЕНИЯМИ РЕФЛЮКС-ЭЗОФАГИТА В ЗАВИСИМОСТИ ОТ СПОСОБА ФОРМИРОВАНИЯ МЕХАНИЧЕСКОГО ПИЩЕВОДНО-ЖЕЛУДОЧНОГО АНАСТОМОЗА \\ Усенко А.Ю., Сидюк А.В., Климас А.С., Сидюк Е.Е., Савенко Г.Ю.}

Формирование механических пищеводно-желудочных анастомозов после эзофагэктомии нередко сопровождается развитием у пациентов рефрлюкс-эзофрагита разной степени. Цель работы - оценить патогистологические изменения слизистой оболочки пищевода, связанные с желудочно-пищеводным рефлюксом, больных раком пищевода и кардиоэзофагиальным раком, после радикального оперативного вмешательства в зависимости от варианта сформированного эзофрагогастроанастомоза. В исследование включены 30 пациентов, которым был сформирован разработанный и защищенный патентом Украины механический инвагинационный эзофагогастроанастомоз (группа исследования) и 30 больных, которым был сфрормирован механический циркулярный эзофагогастроанастомоз конец в бок (группа сравнения). На 12 месяц наблюдения всем больным проведена фриброэзофрагогастродуоденоскопия. Эндоскопическую диагностику рефрюкс-эзофрагита проводили в соответствии с модифицированной Лос-Анджелесской классификацией. Для оценки морфологического состояния слизистой оболочки пищевода выполняли биопсию слизистой оболочки пищевода над местом анастомоза и морфологически оценивали выраженность рефрлюкс-эзофрагита. Рефрлюкс-ассоциированные изменения плоского эпителия пищевода оценивали согласно консенсусным рекомендациям Esohisto Project. Cтатистический анализ данных проведен с использованием пакета статистического анализа EZR v.1.35 (Saitama Medical Center, Jichi Medical University, Saitama, Japan), графический интерфейс к $R$ (The R Foundation for Statistical Computing, Vienna, Austria). При сравнительном 
анализе частотных характеристик между различными группами пациентов использовали критерий 2, для таблиц 22 (в случае малого количества пациентов (<5 случаев) в подгруппах исследования) использован точный критерий Фишера. Различия полученных результатов считали статистически значимыми при р<0,05, что обеспечивает 95\% уровень вероятности. Установлено, что частота, с которой фиксируются микроскопические признаки рефрюкс-эзофрагита, почти в 2 раза ниже в группе больных, которым был сформирован механический инвагинационный эзофагогастроанастомоз по сравнению с механическим циркулярным (46,7\% против 83,3\%, p<0,05), поскольку инвагинация моделирует воспроизведение антирефрюксных свойств утраченного пищеводно-желудочного перехода. Эндоскопически диагностированные случаи рефрюкс-эзофрагита дополнительно дополняются микроскопически обнаруженными от 5,9\% лиц в группе исследования до $28,6 \%$ лиц $(p<0,05)$ в группе сравнения, что свидетельствует о более высокой чувствительности гистологического диагноза. К признакам, которые устойчиво связаны с пострезекционным рефлюкс-эзофагитом отнесено гиперплазию базального слоя как по частоте (86,7\% против 100\%), так и по более тяжелой степени выраженности (6,7\% против 23,3\%, p<0,05), а также умеренное удлинение сосочков (30,0\% против 66,6\%, p<0,01), по которым лучшие результаты получены в группе больных, которым сформировали инвагинационный механический эзофрагогастроанастомоз. По критериям Esohisto Project, частота как "мягкого", так и "тяжелого" эзофрагита в группе больных, которым сформирован инвагинационный механический эзофагогастроанастомоз, была ниже по сравнению с группой с механическим ииркулярным эзофрагогастроанастомозом (36,7\% и 10,0\% против 63,3\% и 20,0\%, p<0,01 соответственно). Таким образом, формирование инвагинационного механического эзофрагогастроанастомоза позволяет достоверно уменьшить частоту гистологических проявлений рефрлюкс-эзофагита по сравнению со способом формирования циркулярного механического анастомоза.

Ключевые слова: проксимальная резекция желудка с резекцией пищевода, эзофагогастроанастомоз, пострезекционный рефрлюкс-эзофрагит, критерии Esohisto Project, гистология, гистопатология. 